\title{
Responsibility in the Age of Emerging Technology
}

As a lawyer, I normally write legal articles for very few readers. We lawyers are happy if some high judges and a few professors from a similar field read our articles and if we are quoted occasionally.

So I was all the more surprised to see that my recent article entitled 'Constitutional Democracy and Technology in the age of Artificial Intelligence ${ }^{\prime 1}$ was downloaded, and I suppose thus read, more than 10,000 times within one month.

What has happened? I can only speculate. Probably many people from academic fields other than law read the article after its content had been reported in the UK newspaper 'The Guardian'. ${ }^{2}$ And indeed, my article was published in a collection of articles on the legal, ethical and technical challenges of governing Al together with articles by engineering professors, professors of philosophy and political scientists. ${ }^{3}$

With the ever more pervasive colonisation of our lives (Jürgen Habermas) by and through markets and technology, there seems to be an ever increasing demand, first and foremost, by the drivers of technological advancement, for rules which provide them with guidance in order to ensure that their inventions are good for society as a whole, and not just for those who seek to draw profit - and increasingly monopoly profit (Peter Thiel) - from new technologies. In the same way that social scientists, philosophers, lawyers and politicians alike need to learn about the new capabilities of the code, the internet of things, artificial intelligence and biophysical systems, to mention just a few marvels of innovation, it seems that the technical innovators seek guidance on purposes to pursue, and how to contribute to democracy, to social justice, to solidarity and fairness. Have all the technologists started to read up on Friedrich Dürrenmatt's 'The Physicists', which every child High School in Germany once had as an obligatory reading assignment? Or Hans Jonas' 'Principle of Responsibility', who in 1979 had already developed the quintessential, and until today unsurpassed, philosophy for the technical age, which resulted in the precautionary principle being taken up in primary constitutional law in the European Union? We can only speculate. But with walk outs of coders and developers in Silicon Valley, with hundreds of books and articles published on ethics and law of new technologies today and numerous working groups being mounted with public or private financing to find a consensus on the way ahead on ethics and law for $\mathrm{Al}$, one thing is clear: There is a need for the

DOI: $10.21552 /$ delphi/2018/1/5

1 Paul Nemitz, 'Constitutional Democracy and Technology in the Age of Artificial Intelligence' (2018) 276 Royal Society Philosophical Transactions A 2133

2 Paul Chadwick, 'To regulate Al we need new laws, not just a code of ethics' The Guardian (London, 28 Ocotober 2018)

3 Corinne Cath, 'Governing artificial intelligence: ethical, legal, and technical opportunities and challenges' 276 Royal Society Philosophical Transactions A 2133 
assessment of new technologies and their impact on society and there are many who want such assessments to be carried out with rigour and in public discourse, and not only behind closed doors by easily captured small groups of the initiated. And there are many who want to make sure that through their work, they do not only contribute to private profits but also to the public good. Technological innovators are no longer naively calling for independence of cyberspace (John Perry Barlow) and are entering a new era defined by taking stock of the societal impacts of their innovations. Some do it out of conviction, some do it because they are being held to account or fear being held to account in the future. Whatever the motivation may be, this is a good thing as with power and capabilities comes responsibility; this is the golden rule of healthy societies and old professions. Understanding and exercising responsibility in the technical age requires interdisciplinary exchanges and dialogue and it requires a multifacetted and early analysis of potential impacts of technology on the many public interests democratic societies share.

Absolutists, whether of the communist or of the capitalist persuasion, want to hear nothing of such impact assessments, and even less of laws which limit profit or innovation in the interest of the public good. As Hans Jonas described so well, this is the space where some from Silicon Valley or Wall Street meet with some from China, a space where financial power combined with technological innovation radically brushes aside any other interest.

But make no mistake, Europe is not free from such tendencies. And of course, there are great thinkers, innovators and entrepreneurs in America and other parts of the world who seek to align their projects with the public interest and who pursue altruistic goals rather than just raw profits.

But nevertheless, there is a geo strategy of innovation, and Europe has chosen to go down the road of guiding innovation towards purpose and responsibility, with the conviction that this in the end will be the most sustainable path from a societal, as well as an economic point of view. It is this spirit which pervades this new publication, the spirit of responsible innovation, which requires impact assessment and interdisciplinary dialogue. May our readers be inspired to contribute to the dialogue across disciplines and to shoulder their responsibilities in line with the technical capabilities they develop and the economic success they may have with their innovations.

Paul Nemitz Directorate-General for Justice and Consumers European Commission 